Meta

Journal des traducteurs

Translators' Journal

\title{
Occupational Integration Training in Translation
}

\section{Olga Torres-Hostench}

Volume 57, numéro 3, septembre 2012

URI : https://id.erudit.org/iderudit/1017091ar

DOI : https://doi.org/10.7202/1017091ar

Aller au sommaire du numéro

\section{Éditeur(s)}

Les Presses de l’Université de Montréal

ISSN

0026-0452 (imprimé)

1492-1421 (numérique)

Découvrir la revue

Citer cet article

Torres-Hostench, O. (2012). Occupational Integration Training in Translation. Meta, 57(3), 787-811. https://doi.org/10.7202/1017091ar

\section{Résumé de l'article}

Le présent article expose une recherche qui a été menée à la Faculté de traduction et d'interprétation de la Universitat Autònoma de Barcelona (Espagne) dont l'objectif est d'évaluer la préparation des diplômés de premier cycle à leur profession. Tout d'abord, un pré-test a été administré aux étudiants pour évaluer leurs compétences globales en termes de connaissances, d'habiletés et d'attitudes, relativement à l'insertion professionnelle. Un programme de perfectionnement a ensuite été élaboré, mis en oeuvre et évalué. Enfin, un post-test, dont les résultats ont été comparés à ceux du pré-test, a été administré aux étudiants. Les résultats de la recherche suggèrent qu'il est nécessaire d'intégrer dans les cours de mastère non seulement des contenus de connaissances relatives au marché du travail, mais également des contenus favorisant chez les étudiants le développement d'habiletés et d'attitudes les aidant à trouver du travail. Notre recherche peut intéresser les professeurs et les responsables de programmes de traduction qui pourraient envisager d'intégrer des cours qui visent l'insertion professionnelle dans les programmes de traduction.
Ce document est protégé par la loi sur le droit d'auteur. L’utilisation des services d'Érudit (y compris la reproduction) est assujettie à sa politique d'utilisation que vous pouvez consulter en ligne.

https://apropos.erudit.org/fr/usagers/politique-dutilisation/ 


\title{
Occupational Integration Training in Translation
}

\author{
OLGA TORRES-HOSTENCH \\ Universitat Autònoma de Barcelona, Barcelona, Spain \\ olga.torres.hostench@uab.cat
}

\section{RÉSUMÉ}

Le présent article expose une recherche qui a été menée à la Faculté de traduction et d'interprétation de la Universitat Autònoma de Barcelona (Espagne) dont l'objectif est d'évaluer la préparation des diplômés de premier cycle à leur profession. Tout d'abord, un pré-test a été administré aux étudiants pour évaluer leurs compétences globales en termes de connaissances, d'habiletés et d'attitudes, relativement à l'insertion professionnelle. Un programme de perfectionnement a ensuite été élaboré, mis en œuvre et évalué. Enfin, un post-test, dont les résultats ont été comparés à ceux du pré-test, a été administré aux étudiants. Les résultats de la recherche suggèrent qu'il est nécessaire d'intégrer dans les cours de mastère non seulement des contenus de connaissances relatives au marché du travail, mais également des contenus favorisant chez les étudiants le développement d'habiletés et d'attitudes les aidant à trouver du travail. Notre recherche peut intéresser les professeurs et les responsables de programmes de traduction qui pourraient envisager d'intégrer des cours qui visent l'insertion professionnelle dans les programmes de traduction.

\begin{abstract}
This article presents the research carried out at the Faculty of Translation and Interpreting at the Universitat Autònoma de Barcelona (Spain) to evaluate how prepared its postgraduates were for employment. First, students were given an initial test to evaluate their competences related to knowledge, skills and attitudes with regard to occupational integration. Next, an improvement program was designed accordingly, implemented and evaluated. Finally, a posttest was given and we compared the results of the pretest and the posttest. The research suggested that there was a need to incorporate into master's and postgraduate courses not only content on knowledge of the translation market and the profession but also content to help students develop specific skills and attitudes for finding a job in translation. This research may interest translation course designers and lecturers, who may want to consider including employment programs in translation courses.
\end{abstract}

\section{MOTS-CLÉS/KEYWORDS}

recherche, traduction professionnelle, insertion professionnelle, emploi, étudiants des cycles supérieurs

research, professional translation, occupational integration, employment, postgraduate students

This article presents the research carried out at the Faculty of Translation and Interpreting at the Universitat Autònoma de Barcelona (UAB) to evaluate how prepared its postgraduates were for employment. First, students were given an initial test to evaluate their competences related to knowledge, skills and attitudes with regard to occupational integration. Next, an improvement program was designed, implemented and evaluated. Finally, a posttest was given and we compared the results of the pretest and the posttest. The article describes the whole research project in 
eight steps. First, we briefly present previous research done within translation studies on career orientation and occupational integration. Second, we present the justification for the research. Third, our research objectives and hypothesis are established. Fourth, we explain the general methodology and the experiment design. Fifth, we describe how we measured the results. Sixth, we explain how we implemented our research and analysed the data. Seventh, we comment on the results. And eighth, we present our conclusions.

\section{State of the question}

Since translation is a profession with a long history and the main employment perspective for a graduate in Translation and Interpreting is to become a translator or interpreter, it seems reasonable to assume that there must be substantial research done on Translation Studies to help graduates become professional translators. There is indeed considerable research, but in analysing the existing literature we found that some aspects in the field are more developed than others. Some authors focus on the knowledge necessary to break into the profession (Díaz Ferrero and Sabio 2003; Samuelsson-Brown 1998; Valero 2003; Wagner, Bench et al. 2002; Sofer 2004; Tolnai 2008). Some focus on market description and market requirements (Carsten 2002; Gouadec 2002; Groethuysen 2002; Gromová and Müglová 2003; Waliczek 2002; Roser 2004; Wills 1999; Phillips 1996; Chaballe and Klein 1994; Jiménez 2002; Monzó 2002; Díaz Cintas 2003; Chaume 2003; Parra 2002; Aubert 1995; Aguilar Río 2004; Ulrych 1996; Casas-Tost and Rovira-Esteva 2008; Fišer 2008; Lung Jan Chan 2010). Some researchers have studied professional translators' profiles and their qualifications (PACTE Group 2001; 2002; 2005; Asadi and Séguinot 2005; Tirkkonen-Condit 2005; Willss 1996; Kiraly 2000; Robinson 1997; McDonough 2007; Katan 2009; Dam and Korning Zethsen 2009). Still other authors, such as Bowker (2004), have analysed job offers for translators in order to include market demands in translators' training. On the other hand, some studies focus on job placement and students (Kelly 2004; ANECA 2004; Observatori Ocupacional UJI 2003; OPQ 2003; Wagner, Bench et al. 2002). Other authors focus on developing skills for job placement (Byrne 2003; Teichman 2003; Ulrych 1996). Finally, some authors, such as Wakabayashi (2002) and Alcina-Caudet (2003), focus on developing the right attitudes for occupational integration. This last category could include real-life translation projects, enabling students to develop the knowledge and attitudes needed to become professionals. Such projects include simulations and direct professional experience (Lavault-Olléon 1998), simulations of the translator's workstation (Borja, Gamero Pérez et al. 1998) and the Tradutech project (Gouadec 2003), ${ }^{1}$ which involved more than thirteen European universities and included all aspects of technical translation training, from basic training to the final integration into employment. As stated in the project presentation: "L'enseignement débouche ainsi directement sur la profession en introduisant graduellement l'étudiant dans son milieu professionnel. Il s'agit en quelque sorte d'un continuum Centre de formation - Emploi" (Gouadec 2003).

As we can see from the above-mentioned works, the market is one of the aspects most studied by researchers. However, our research is based on less-studied aspects such as the process of orientation for employment, which lies somewhere between the research on the market and research on translators' training. Occupational integration 
training deals specifically with the preparation of students for integration into the translation market, which is the missing link between postgraduates and the market (Torres-Hostench 2010).

\section{Justification for the research}

Although traditionally occupational integration rate of graduates in translation and interpreting in Spain has been high (see Table 1), there is also some unemployment.

TABLE 1

Employability of translation and interpreting graduates in Spain

\begin{tabular}{|l|c|c|c|c|}
\hline Employability & ANECA Data $^{2}$ & UAB/AQU Data & UAB/FTI Data & UJI Data \\
\hline Employed & $74.2 \%$ & $89.7 \%$ & $85.3 \%$ & $93.8 \%$ \\
\hline Unemployed & $18.5 \%$ & $8.1 \%$ & $14.7 \%$ & $6.3 \%$ \\
\hline
\end{tabular}

Sources: various sources between 1999 and 2003. See Note 2.

For instance, the UJI data included answers from the unemployed graduates (6.3\%), who gave as their main reason for being unemployed the fact that they had not studied a specialized master's course in translation after graduation, the financial crisis, and their lack of contacts. Nevertheless, not all employed graduates work in the translation sector, as seen in Table 2 below.

TABLE 2

Employment sectors of translation and interpreting graduates

\begin{tabular}{|l|c|c|c|c|}
\hline Employment sectors & ANECA Data $^{3}$ & UAB/AQU Data & UAB/FTI Data & UPCO Data \\
\hline Translation & $86.6 \%$ & $25 \%$ & $34.2 \%$ & $33 \%$ approx. \\
\hline Language teaching & $29.6 \%$ & $14.4 \%$ & $16.4 \%$ & $3 \%$ approx. \\
\hline $\begin{array}{l}\text { Administrative jobs } \\
\text { in companies }\end{array}$ & $28.3 \%$ & $46 \%$ & $34.2 \%$ & $30 \%$ approx. \\
\hline $\begin{array}{l}\text { Interpreting } \\
\text { Services }\end{array}$ & $14.3 \%$ & $2.4 \%$ & $\begin{array}{c}\text { (included under } \\
\text { Translation) }\end{array}$ & $5 \%$ approx. \\
\hline Others & $12.1 \%$ & N/A & N/A & $29 \%$ approx. \\
\hline
\end{tabular}

Sources: various sources between 1999 and 2003. See Note 2.

- Translation comprised the following jobs: freelance translator, translation project manager, translator in a language industry company or in another kind of company;

- Language teaching comprised language teachers in private as well as public schools and/or universities;

- Administrative jobs comprised administrative staff, secretaries, import-export employees;

- Interpreting comprised conference interpreters, social and cultural mediators and court interpreters;

- Others comprised receptionists, public relations staff, salespersons, hostesses, call center staff, shop assistants, consultants (linguistic, pedagogic or commercial), services coordinators, computer technicians and those working in mass media and travel agencies. 
As seen in Table 2 many graduates work in administrative and language-related professions (around 30\%-40\%) or in language teaching (20\%), but not doing full-time translation tasks. In many cases, the change of career from translation to other occupations might be a personal decision. However, it seems that graduates who have jobs related to translation are more satisfied with them. For instance, in UAB/FTI Data, graduates had to rate between 1 and 7 their satisfaction with their current job. Translation jobs scored 5.14; Language teaching jobs scored 5; Others scored 4.63 and Administrative jobs scored 4.53.

It would be interesting to know how many real translation offers for translation graduates were available at the time of the study and the proportion between offers and graduates. This information was not analysed in the study and it cannot be presented here. In future similar research it would be interesting not only to record employment data (figures and profiles) but also to analyse available translation offers. Although we cannot provide information on offers, we do have information on how students got their jobs (Table 3). Contacts and referrals are main work sources. This may indicate that many translation offers are not often public but are transmitted from customers/companies to translators individually or via personal contacts.

TABLE 3

Forms of access to jobs

\begin{tabular}{|l|c|c|c|}
\hline Work access & UAB/AQU Data & UAB/FTI Data & UJI Data \\
\hline Contacts & $50 \%$ & $33.8 \%$ & $\begin{array}{c}51.8 \% \\
\text { (18.5\% for personal } \\
\text { contacts and 33.3\% for } \\
\text { graduates contacting } \\
\text { companies directly) }\end{array}$ \\
\hline Press & & & $14.8 \%$ \\
\hline Self-employed & $26.7 \%$ & $16.2 \%$ & N/A \\
\hline Temporary work agencies & N/A & $8.8 \%$ & $11.1 \%$ \\
\hline Internet & $6.7 \%$ & $8.1 \%$ & N/A \\
\hline Public examination & N/A & $7.3 \%$ & N/A \\
\hline Recruitment agencies & N/A & $5.1 \%$ & N/A \\
\hline University occupational services & N/A & $5.1 \%$ & N/A \\
\hline Public employment agencies & N/A & $1.4 \%$ & $3.7 \%$ \\
\hline Others & $13.2 \%$ & $0.8 \%$ & $18.5 \%$ \\
\hline
\end{tabular}

Sources: various sources between 1999 and 2003. See Note 2.

Up to $50 \%$ of UAB translation graduates find work through contacts and networking (OPQ 2003), but they do not make the most of other ways of finding work. Thus, it was our contention that the present research helped to improve job placement quality and uncovered new ways of accessing the profession, as well as explaining real translation market conditions to graduates.

Before concluding this section, we should make it clear that none of the questionnaires used to gather the data presented in the tables above explicitly referred to the orientation for occupational integration provided by faculties. The universities had a major interest in using the questionnaires to see whether the courses helped students in their future jobs and whether the knowledge and skills they learned were applicable to their jobs. But nothing was asked regarding orientation for students in 
finding their job. Clients have also mentioned this lack of and need for orientation for occupational integration (ANECA 2004).

We shall conclude this section by stating something that is rather obvious: it should come as no surprise that there is a lack of orientation for the occupational integration of graduates if no provision is made for this kind of training in course syllabuses. We thus created a global program for orientation for occupational integration that included defining the need and justification for orientation, establishing the objectives, presenting the theoretical models that would enable all the issues to be considered, and creating an application model that would enable the program to be introduced, with provision made for an ongoing, exhaustive evaluation process. This is certainly a very innovative approach that is very different from leaving orientation for occupational integration to chance.

The students who participated in the research project belonged to one of the following student profiles: those who were employed in other sectors and wanted to study the master's course to find a job in translation; those working in translation who wanted to improve their specialised translation skills; and those who had graduated recently and still had not found work. In all cases, though, the main reason for studying the master's course was to keep or find a job in translation.

\section{Research objectives and hypothesis}

We designed the research after carrying out a detailed analysis of the research context and identifying the needs of this context, i.e., the needs of postgraduate and master's students in terms of occupational integration, as is further explained below. Besides interviewing experts on occupational integration and reviewing the literature on occupational integration within the framework of translation studies, we carried out an initial evaluation of the context in which we wanted to carry out our research. First, we analysed the content of the master's courses to see what they were already doing on occupational integration besides offering translation internships. We also analysed the profiles of the coordinators, lecturers and students. Then, we interviewed the coordinators to find out exactly what their needs were in terms of occupational integration. In this analysis we already detected three general needs: first, students needed to improve their knowledge of the translation market; second, students needed to develop specific skills to find work; and third, they needed to be responsible for their occupational integration and devote some time to this task. Specific needs varied from one master's course to another because each course offered different subjects and content related to the profession. Therefore, different actions should be undertaken for each master's course, as will be presented later.

In order to transform the general needs into specific research objectives, different theoretical models related to occupational integration were studied and a reference model was chosen for our research. Montané's model (1990) was chosen, since it includes factors and variables for occupational integration related not only to the professional market or the person looking for work, but also to the techniques and processes that should be developed in order to improve one's training in occupational integration. As we were interested in improving students' training, this model was especially useful. Moreover, it was easy to understand and to apply. Montané's model suggests analysing: 
a) Knowledge for occupational integration, i.e., knowledge needed to get access to a desired job. In our case, it would imply information on where to get a translation job, how to access the translation market, etc.;

b) Skills for occupational integration, i.e., skills to be mastered to succeed in a job recruitment process. For instance, how to prepare a CV for the translation market, how to prepare for an interview, how to approach a translation test, etc.;

c) Attitudes for occupational integration, i.e., attitudes that are relevant when looking for work, such as dedication, flexibility, professional maturity and professional selfesteem.

All these factors will be explained in greater detail later.

Montanés occupational integration model was complemented with quality models to organize research more accurately. The quality models reviewed were the ISO model, the EFQM Model and the Total Quality Management model, which are not described in this article as they are popular enough to be considered of general knowledge for researchers. Based on the general detected needs and Montanés occupational integration model, a series of objectives was established. As a general objective, we decided that the training of postgraduates in occupational integration needed to be improved in order to achieve a change in their knowledge, skills and attitudes when looking for work. As specific objectives, we determined that students needed:

a) to get information and know the real translation market in order to have a realistic view - objective inspired by Montané’s factor "knowledge for occupational integration";

b) to learn specific skills to succeed in the selection process for a translation job - an objective inspired by Montané's factor "skills for occupational integration";

c) to improve specific attitudes for occupation, such as dedication - objective directly inspired by Montané's factor "attitudes for occupational integration."

We believed our objectives were realistic and could be encouraged in class. Of course, there are also other aspects involved in an employment process, but some depend exclusively on the postgraduates, such as their personality, their CV, etc., while others depend on the market, such as professionals' competences or the number of employment offers available to postgraduates (which, as mentioned before, were not analysed). To achieve our objectives, we designed a training improvement program (hereinafter, the OIL Program). From the general objective we established a hypothesis that we would be able to confirm or reject at the end of the research. Our hypothesis was the following: with the OIL Program, postgraduates would improve their knowledge, skills and attitudes in occupational integration. The hypothesis validation as well as the OIL Program will be explained later in this article.

\section{General methodology and experiment design}

A total of 122 postgraduates from the Universitat Autònoma de Barcelona (Spain) took part in the experimental research carried out in 2005. They were distributed in five groups: three experimental groups and two control groups. The classification between experimental and control groups was made after the interviews with the master's courses coordinators where they were informed about the research and the OIL Program. From a strictly scientific point of view, the five groups were adequate to be experimental as well as control groups. Each coordinator decided whether to participate as an experimental or control group depending on the support that could 
be offered to the research. As a matter of fact, from a statistical point of view, it would have been better to mix students from the five courses and distribute students in experimental and control groups randomly. However, this option did not allow coordinators to follow the progress of their groups individually, nor did it enable specific actions for each master's course to be prepared, which was one of the objectives of the OIL Program. In the end, the groups were divided as shown in Table 4.

TABLE 4

Brief description of groups

\begin{tabular}{|c|c|c|c|c|c|}
\hline & $\begin{array}{c}\text { Master's in } \\
\text { Audiovisual } \\
\text { Translation }\end{array}$ & $\begin{array}{c}\text { Master's in } \\
\text { Translation } \\
\text { and New } \\
\text { Technologies }\end{array}$ & $\begin{array}{l}\text { Postgraduate } \\
\text { course in } \\
\text { Legal } \\
\text { Translation } \\
\end{array}$ & $\begin{array}{l}\text { Postgraduate } \\
\text { course in } \\
\text { Literary } \\
\text { Translation } \\
\end{array}$ & $\begin{array}{c}\text { Postgraduate } \\
\text { course in Editing } \\
\text { and Language } \\
\text { Quality }\end{array}$ \\
\hline Group type & Experimental & Experimental & Experimental & Control & Control \\
\hline No. students & 32 & 25 & 23 & 16 & 26 \\
\hline Female & 28 & 23 & 20 & 11 & 25 \\
\hline Male & 4 & 2 & 3 & 5 & 1 \\
\hline Students under 25 & 24 & 17 & 15 & 7 & 15 \\
\hline $\begin{array}{l}\text { Students with previous } \\
\text { Trans. \& Int. studies }\end{array}$ & 18 & 21 & 17 & 3 & 7 \\
\hline \multicolumn{6}{|l|}{ EMPLOYMENT } \\
\hline Full-time students & 11 & 8 & 2 & 3 & 7 \\
\hline $\begin{array}{l}\text { Worked from time-to- } \\
\text { time }\end{array}$ & 11 & 9 & 7 & 3 & 10 \\
\hline Worked part-time & 4 & 2 & 4 & 3 & 7 \\
\hline $\begin{array}{l}\text { Worked full-time (as } \\
\text { freelance translators in } \\
\text { brackets) }\end{array}$ & $5(2)$ & $6(2)$ & $8(2)$ & $6(1)$ & 2 \\
\hline $\begin{array}{l}\text { Had previously worked } \\
\text { in translation }\end{array}$ & 5 & 2 & 2 & 2 & 0 \\
\hline
\end{tabular}

Ten lecturers from the five different master's and postgraduate courses also participated in the OIL Program. Moreover, 90 students participated in the pilot experiment that took place the previous year. In total, more than 220 people were involved in this research project. The research followed a pretest-posttest design (Table 5) and some variables were identified (Table 6).

TABLE 5

Research design structure

\begin{tabular}{|l|l|}
\hline Pilot groups & Pretest-----------------------Posttest \\
\hline Experimental groups & Pretest----[OIL Program]----Posttest \\
\hline Control groups & Pretest-----------------------_Posttest \\
\hline
\end{tabular}

TABLE 6

Independent and dependent variables present in the research project

\begin{tabular}{|l|l|l|}
\hline OIL Program & Lecturers & Postgraduates \\
\hline DV1 & DV2 & DV3 \\
\hline IV1 & IV2 & \\
\hline
\end{tabular}


Independent variables are those variables manipulated by the researcher, i.e., those elements deliberately manipulated to test the results of the research. In our research, the first independent variable (IV1) is the OIL Program, as the results vary depending on the implementation of the program in each group. The second independent variable (IV2) are the lecturers, as they were the ones who applied the program to postgraduates. Section 7 explains how results were affected by different independent variables.

It is the dependent variables (elements and people's behaviours) that are measured, as they are supposed to be changed by the independent variables. The first dependent variable (DV1) in our research is the OIL Program per se, as it is the first finished product obtained during the research. As we can see, the OIL Program can be either an independent or a dependent variable, depending on its function in the research. The second dependent variable (DV2) is the lecturers, as they too receive the program before passing it on to the students. Lecturers are therefore also both an independent and a dependent variable. The third dependent variable (DV3) is the postgraduates, who are evaluated in the posttest to check whether any changes have taken place since the beginning of the intervention. Alien variables are variation dimensions that may confuse the action of manipulated independent variables. In our research, alien variables are personal and professional features of the students, as well as the contents of master's and postgraduate courses. In order to monitor them, we recorded them. All information produced during the research was properly recorded and saved. Table 7 summarizes the documentation used, produced and compiled during the research.

TABLE 7

Documentation used in the research

\begin{tabular}{|c|c|}
\hline Material produced for the research & Material compiled during the research \\
\hline $\begin{array}{l}\text { - Administrative research documentation } \\
\text { (internal) } \\
\text { - Research presentation documentation } \\
\text { (prepared for lecturers and coordinators) } \\
\text { - Pretest questionnaire } \\
\text { - Reports on the pretest results with totals and } \\
\text { by group } \\
\text { - Dossier with OIL activities } \\
\text { - Evaluation forms and other research material } \\
\text { - Final results reports }\end{array}$ & $\begin{array}{l}\text { - Pretest questionnaires answered by students } \\
\text { - OIL Activities prepared by professors } \\
\text { - Posttest questionnaires answered by students } \\
\text { - Evaluation of participants (students, lecturers } \\
\text { and master's/postgraduate courses } \\
\text { coordinators) }\end{array}$ \\
\hline
\end{tabular}

\section{The instrument of measure: the pretest-posttest questionnaire}

A pretest-posttest questionnaire was designed to measure the degree of postgraduates' training in occupational integration. The questionnaire had 30 items that evaluated knowledge, skills and attitudes related to occupational-integration training, and a few preliminary items to define the personal profile of students and their employment situation. The Appendix contains the final version of the questionnaire. This instrument was validated by experts, and confidence levels were measured statistically using the Cronbach coefficient Alpha (0.741 for 32 items).

The pretest-posttest questionnaire we used in our research was adapted from two sources: Montané (1993: 166) and Pérez Escoda (1996: 156). The clearest difference 
between these two questionnaires and ours is that the former are addressed to anybody looking for a job, whereas ours is addressed specifically to translators, whether they are looking for a job in a company or self-employed work. As we shall see in the detailed description of the items in the questionnaire, the items are related to our research objectives and hypothesis: the improvement of knowledge, skills and attitudes for occupational integration in translation. Next there is a description of the questionnaire. The Appendix contains a final version of the questionnaire for reference. This pretest-posttest questionnaire has a double function. On the one hand it reveals students' training in occupational integration (which is useful for us), while on the other it provides a tool to make students aware of what they do for their occupational integration (this function is very useful for them). It was difficult to choose only 30 indicators (this was the maximum we established in order to be able to control them properly), but we chose relevant indicators that not only were good examples of the knowledge, skills and attitudes we wanted to test, but also would be clear enough to make students think about their own occupational process after completing the questionnaire.

The first part of the questionnaire asks students to answer some general questions on their profile. This information is used to know the students better and to control alien variables. Students must write their name, age, the degree they studied before the postgraduate or master's course, the year they finished their degree, the postgraduate or master's course they are studying, their current employment, their desired employment, their experience in the job and general information on their work experience.

The second part of the questionnaire is designed to evaluate knowledge on occupational integration. Students have to answer whether they know what translation customers offer, and what they ask from a translator, what the legal and fiscal obligations are, and if they know any free employment services where they live.

The third part of the questionnaire contains items that evaluate skills in occupational integration. The degree of expertise is evaluated using the following indicators: having a professional website, having and distributing marketing material, having a plan or strategy to look for clients, knowing how to find employment or translation work, knowing how to sell translation services, and knowing how to keep clients satisfied. Some questions are too general or subjective, such as number 9 (Do you know how to sell translation services to a new client?) or 10 (Do you know how to keep clients satisfied?). We are interested here in the student's perception of this issue, not in specific answers. If they feel they are able to sell services or satisfy clients, it means they feel they have the specific skills to do so (in this section we are testing skills), whereas if they feel they are not ready to deal with clients, hopefully, at the end of the test, they would think that they should do something about it so that they would be more open to the OIL program, for instance.

In the fourth part of the questionnaire, students answer some questions on dedication to occupational integration. This serves to evaluate the university degree of activity in the following areas: contacting companies personally or by phone in the last 30 days, sending curriculum vitae or answering translation offers in the last 30 days, having translation tests or interviews pending, how much time students devote to occupational integration and if they would go to an occupational integration course. 
The fifth part of the questionnaire is about flexibility in occupational integration, i.e., whether students would be flexible regarding working conditions. For example, whether they would accept a similar translation job to the desired job, whether they would accept lower rates or working in lower working conditions than expected, whether they would accept working somewhere other than they expect and whether they would accept irregular working hours.

The sixth part of the questionnaire evaluates professional maturity, i.e., the student's capacity to be really interested in a job and to value the pros and cons of a job. In this area, students were asked whether what they read is related to their profession, whether they are members of professional associations, whether they are technologically prepared and whether the reason for studying the master's or postgraduate course is to look for a translation job or for other reasons.

The last part of the questionnaire is about professional self-esteem. In order to evaluate professional self-esteem students answer questions on their own perception as professionals, such as the professional perception they think that their friends and colleagues have of them, their own perception of being able to offer added value to their translation services, their own perception on the possibilities of finding work, their determination when looking for work and their optimism or pessimism when looking for work.

Each item had three or four possible answers (depending on the item). Each answer was converted to a numeric value from 0 to 2 . Items with three possible answers were converted to a 0,1 or 2 value and items with four possible answers were converted to a $0,1,1.5$ or 2 value. This allowed us to compare values at the end of the research between groups, as presented in section 7 ("Global Results").

The pretest questionnaire was given to the pilot group of 90 students in January 2004 from four master's courses (Audiovisual Translation, Legal Translation, Translation and New Technologies, and Literary Translation). In the pilot test students were different from students from control and experimental groups. In this pilot test the validity of the instrument of measurement and the appropriateness of the research were tested. Based on the results we made some minor changes to the design, implementation and assessment method for the questionnaire.

\section{Implementation and data analysis}

In the experiment in 2005, the pretest was given to 122 participants (control groups and experimental groups). During the pretest, notes were taken on technical problems and any other significant information, whether positive or negative, to improve the pretest for future editions. Afterwards, the pretest data were processed and, based on the results, the lecturers and the research coordinator designed a series of activities to improve the results. For the improvement program, specific material was designed and up to ten lecturers cooperated by preparing their own material. The improvement program was implemented in class so that lecturers of the postgraduate and master's courses, most of whom are also professionals in the translation market, indirectly trained students in occupational integration in their courses. Finally, the posttest questionnaire (which was the same as the pretest questionnaire) was given to the students in order to compare its results with the pretest results. 
The results of the posttest were analysed by comparing the experimental groups and control groups to find out whether there were actually any changes in postgraduates' knowledge, skills and attitudes related to occupational integration since the program had been implemented. The results were processed with the statistical software SPSS. Specific results according to each of the questionnaire's items and by group were also analysed in the research and given to each master's course coordinator for their reference.

In order to clarify duties and responsibilities for different participants of the research, Figure 1 gives a graphical representation of the relationships established between participants and a list of each participant's duties and responsibilities.

FIGURE 1

\section{Relationship between participants}

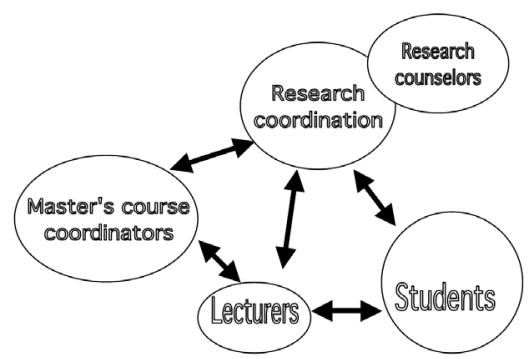

The research supervisors' main responsibility was to provide advice on the design, implementation and evaluation phases of the research.

The responsibilities of the research coordinator were: designing research from analysed models taking into account the context; informing participants about research and the OIL Program; encouraging and motivating master's courses coordinators, lecturers and students to participate; elaborating research materials and OIL Program; recopilating and analysing data and materials for research and for the OIL Program; preparing research reports; managing OIL Program activities; evaluating the research and the OIL Program with participants and, last but not least, disseminating the results.

Among responsibilities of master's courses coordinators were accepting and supporting the research; informing lecturers and students about the OIL Program and evaluating the OIL Program with the research coordinator (design and implementation).

Lecturers' main responsibilities were familiarizing themselves with the research and supporting it; implementing OIL activities in their classes; encouraging students to participate; and evaluating the OIL program with the research coordinator.

As for students, they were expected to participate actively in the research (completing the pretest and posttest questionnaires, completing OIL activities and evaluating the OIL Program).

Table 8 details the timing for the pilot groups and Table 9, the timing for the experimental groups. 
TABLE 8

Implementation for the pilot groups

\begin{tabular}{|l|l|}
\hline Information to master's courses coordinators & November 2003 \\
\hline Execution of the pretest questionnaire & January 2004 \\
\hline Interpretation of results and detection of needs & January - February 2004 \\
\hline $\begin{array}{l}\text { Sending of results to coordinators, students and the directors of the } \\
\text { Department of Translation and Interpreting }\end{array}$ & March 2004 \\
\hline $\begin{array}{l}\text { Based on the results of the pilot groups, preparation of the OIL } \\
\text { Program for experimental groups (OIL Dossier and OIL activities) }\end{array}$ & April 2004 - July 2004 \\
\hline
\end{tabular}

TABLE 9

Implementation for the experimental groups

\begin{tabular}{|l|l|}
\hline Information to master's courses coordinators & September 2004 \\
\hline Information to master's courses lecturers to encourage participation & October 2004 \\
\hline Pretest execution & September - October 2004 \\
\hline Preliminary analysis of data & October 2004 \\
\hline $\begin{array}{l}\text { OIL Dossier sent to lecturers (OIL Dossier addresses the lowest } \\
\text { results from the pretest) }\end{array}$ & October 2004 \\
\hline OIL Dossier sent to students & November 2004 \\
\hline $\begin{array}{l}\text { Final statistical results of the pretest are sent to master's course } \\
\text { coordinators, lecturers and students }\end{array}$ & January 2005 \\
\hline OIL activities done by lecturers in class & March - May 2005 \\
\hline Posttest execution & May 2005 \\
\hline Analysis of results & June - July 2005 \\
\hline Dissemination of results to participants & October 2005 \\
\hline
\end{tabular}

\subsection{The OIL Program}

The OIL Program consisted of the OIL Dossier prepared by the research coordinator and OIL activities implemented by lecturers in class.

\subsubsection{The OIL Dossier}

The OIL Dossier consisted of 40 activities distributed in five units that students could carry out. To encourage participation at the beginning of the program, students did not receive the five units from the beginning. They would do the activities for one unit, send an evaluation questionnaire to the research coordinator and, once the questionnaire was received, the following unit was sent to the student. The first unit was sent in November. As the participation in the Program was voluntary, not all students participated (from the three experimental groups, in one group students participated just in one unit, in another group students participated in two units, and in the third group students participated in four out of five units). In February, once the final statistical results from the pretest were available, a full version of the Dossier was sent to students to give them a second chance to participate and a brief OIL Dossier evaluation questionnaire was sent to students to check if students had done the activities, and their opinions.

It is worth mentioning that the group in which students participated in the five units had higher posttest results than the other groups, so there is a direct relation- 
ship between active participation in the OIL Dossier and the final results of the group. Moreover, students who completed the OIL Dossier valued it positively as a tool for occupational integration.

The OIL dossier is useful for students if they produce the dossier themselves, and is useful for lecturers if they want to do some of the activities in groups in class.

The OIL dossier contains five topics:

1) The idea of the professional project;

2) Web and e-mail addresses I'm interested in;

3) The distance marketing campaign;

4) Direct contact: telephone and interviews;

5) Creating an action plan.

The order of the topics is coherent with the logical progression of the search for a job. Most of the activities are related to one of the items in the occupational integration questionnaire and aim to improve the results of the questionnaire. The first version of the OIL dossier was produced based on the results of the questionnaires in the pilot study.

The activities in the first topic, entitled "The idea of the professional project," deal with the general approach to the professional project and defining the job the student is seeking. This idea is related to the student's personal profile and certain elements of the labour market, such as competence, so students can redefine their employment objectives and make it more realistic. The proposed activities and reflections are as follows:

In activity 1.1, entitled The job I'm looking for, students define the jobs they want in as much detail as possible so they can identify information they lack and what they need to ask. In this activity, students work on maturity for employment. In activity 1.2, entitled The job ad I'm looking for, students say what specific job they want. This exercise enables students to clearly state their objectives. In activity 1.3, entitled The clients I'm interested in, students establish what clients they want to work with. This activity also focuses on students' maturity for employment. In activity 1.4, entitled In the client's shoes, students identify what translation services clients of interest may ask for. Students also work on their knowledge of occupational integration in this activity. In activity 1.5, entitled You and the client, students consider how they can improve the services they offer clients to gain a competitive edge. In this activity, students work on various attitudes, including professional self-esteem. In activity 1.6, entitled The benefits of the job, students analyse the job they want to do in greater detail. In this activity, students work on maturity for employment. In activity 1.7, entitled The opportunities and threats of my profile, students analyse the strengths and weaknesses of their profile. This information helps them to adjust their choice of job, if necessary. In this activity, students work on maturity for employment and professional self-esteem. In activity 1.8, entitled What makes you different from your competitors, students become aware of the concept of competition and incorporate measures into their action plan to deal with competition. In this activity, students work on maturity for employment.

Once the professional objective has been clarified, the second topic is introduced. Entitled Web and e-mail addresses I'm interested in, it aims to enable students to gather together the addresses they need to achieve their objective. In this phase, students do not contact clients. They simply compile the necessary information. In 
activity 2.1, entitled Translators' associations, students find out about the different translators' associations and consider whether they should join an association. In this activity, students work on maturity for employment. In activity 2.2, entitled Occupational integration paths, students explore the different occupational integration paths they can use to reach the clients they are interested in. Students work on their knowledge of occupational integration in this activity. In activity 2.3, entitled My register of addresses, students produce a single document containing the addresses they have so they can subsequently contact potential clients. Students work on their occupational integration skills in this activity. In activity 2.4, entitled New addresses, students produce a register of addresses of companies they would like to contact. Students work on their occupational integration skills in this activity. In activity 2.5, entitled Improving networking, students become aware of the importance of contacts when looking for work. In this activity, students work on maturity for employment and knowledge of occupational integration.

Once students know what they want to do and have the addresses they need, their next step is to produce the promotional material they want to send to their potential clients. The activities in the third topic, entitled The distance marketing campaign, are preceded by a short introduction on promotional material. In activity 3.1, entitled The website, students become aware of the importance of a website to professional translators. Students are given some advice on designing a website. In this activity, students work on maturity for employment and occupational integration skills. In activity 3.2, entitled The business card, students produce a business card. Students work on their occupational integration skills in this activity. In activity 3.3, entitled The résumé, students learn how to produce a résumé. Students work on their occupational integration skills in this activity. In activity 3.4, entitled The cover letter, students learn how to write a cover letter. Students work on their occupational integration knowledge and skills in this activity.

Once students have established what type of job they want (first topic), gathered together the addresses of contacts and companies related to that type of job (second topic), and prepared the distance marketing material (third topic), they must then prepare for directly contacting potential clients in the fourth topic, entitled Direct contact by telephone and in interviews. Activities 4.1 to 4.6, entitled Contact by telephone, give students preparation and practice for their first contact with potential clients. Students work on their occupational integration knowledge and skills in this activity. In activities 4.7, 4.8 and 4.9, entitled Preparing for interviews, students practice basic strategies to prepare for an initial interview with possible clients. Students work on their occupational integration knowledge and skills in these activities. In activity 4.10, entitled The interview, students receive strategic advice on holding an initial interview with a potential client. Students work on their occupational integration knowledge and skills in this activity.

In the fifth topic, entitled Creating an action plan, students must produce an action plan with a detailed schedule, since everything else is now ready: the choice of potential clients (first topic), the addresses (second topic), the promotional material (third topic) and the strategies for the initial contact (fourth topic). The activities in this topic aim to help students in the area of work commitment. A week-long action programme is prepared, the contacts established are followed up, the action programme is reviewed and the unachieved objectives are analysed. 


\subsubsection{Activities done by lecturers}

Lecturers volunteering to participate could choose an activity from a menu of occupation activities prepared by the research coordinator and/or prepare their own activities with the support of the research coordinator.

Table 10 provides a summary of the activities done by lecturers in each group. It is worth mentioning that although the program is the same for all groups, some activities were different because lecturers could choose the activities taking into account the students, the subject, etc. This freedom to choose is positive for the program's success as it allows customization of contents.

TABLE 10

Activities done by lecturers in experimental groups

\begin{tabular}{|l|l|l|}
\hline Master's Course & Lecturer & Activity \\
\hline Audiovisual Translation & Lecturer 1 & $\begin{array}{l}\text { PowerPoint with OIL Dossier activities (and } \\
\text { activities were commented in class) (2 classes) }\end{array}$ \\
\hline Audiovisual Translation & Lecturer 2 & $\begin{array}{l}\text { Students prepared their résumé in English to work } \\
\text { as audiovisual translators (2 classes) }\end{array}$ \\
\hline Audiovisual Translation & Lecturer 3 & PowerPoint with OIL Dossier activities (3 classes) \\
\hline Audiovisual Translation & Lecturer 4 & PowerPoint with OIL Dossier activities (3 classes) \\
\hline Legal Translation & Lecturer 1 & PowerPoint with OIL Dossier activities (5 classes) \\
\hline Legal Translation & Lecturer 2 & $\begin{array}{l}\text { Students prepared their résumé and presentation } \\
\text { letter in English to work as legal translators (1 class) }\end{array}$ \\
\hline $\begin{array}{l}\text { Translation and New } \\
\text { Technologies }\end{array}$ & $\begin{array}{l}\text { Simulation of a real translation project, where } \\
\text { students played different roles (project manager, } \\
\text { translator, desktop publisher and engineer) (1 class) }\end{array}$ \\
\hline $\begin{array}{l}\text { Translation and New } \\
\text { Technologies }\end{array}$ & Lecturer 2 & $\begin{array}{l}\text { Students prepared a website to sell their services as } \\
\text { professional translators using the software tool that } \\
\text { the lecturer taught in class (4 classes) }\end{array}$ \\
\hline $\begin{array}{l}\text { Translation and New } \\
\text { Technologies }\end{array}$ & Lecturer 3 & $\begin{array}{l}\text { Students had to prepare a real quotation for a } \\
\text { website localization using a software tool presented } \\
\text { by the lecturer (3 classes) }\end{array}$ \\
\hline $\begin{array}{l}\text { Translation and New } \\
\text { PowerPoint with OIL Dossier activities (2 classes) }\end{array}$ \\
\hline
\end{tabular}

In the evaluation of the OIL Program, students valued activities done by lecturers positively. The highest ++ score was for Translation and New Technologies activities, probably because these activities were more related to the master's course contents. Lecturers also valued positively the activities and some mentioned as ideas for improvement to integrate more of these activities in the master's course subjects and devote more time to this content. Some lecturers commented that they see many students are lost and do not make the most of the resources that they and/or the master's course offers to them. The direct approach of the OIL Program could help to address this situation. 


\section{Global results}

This section presents the statistical results of the experimental stage. They will show whether postgraduates (dependent variable) have been affected by the OIL Program consisting of the OIL Dossier and activities prepared by lectures (independent variables). There are no global results for the pilot test. We only have the pretest results, which were used to refine the questionnaire, identify the items with the lowest score and prepare the OIL Dossier accordingly. It is worth mentioning that pilot pretest results coincided mostly with the results in the experimental stage.

In the experimental stage, from the pretest-posttest questionnaires we extracted an overall average score of between 0 and 2, as explained in the presentation of the questionnaire. The global average for all the pretest answers was 0.88 and the global average for all posttest answers was 1.03. The global averages are represented in Figure 2. There was only a small difference of 0.15 between the pretest and posttest average.

FIGURE 2

Comparison between global pretest and posttest averages

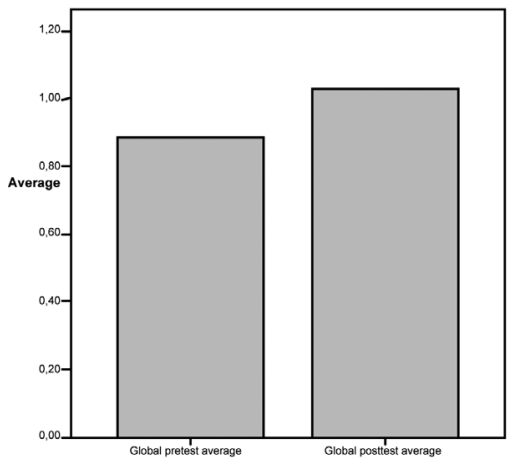

In Figure 3 we can see a comparison between the global averages of the experimental groups (pretest 0.93 and posttest 1.09) and the control groups (pretest 0.80 and posttest 0.91 ). The global average shows little change between the pretest and posttest stage. However, there are clearer differences between groups and between specific items.

FIGURE 3

Comparison between global pretest and posttest averages in experimental and control groups

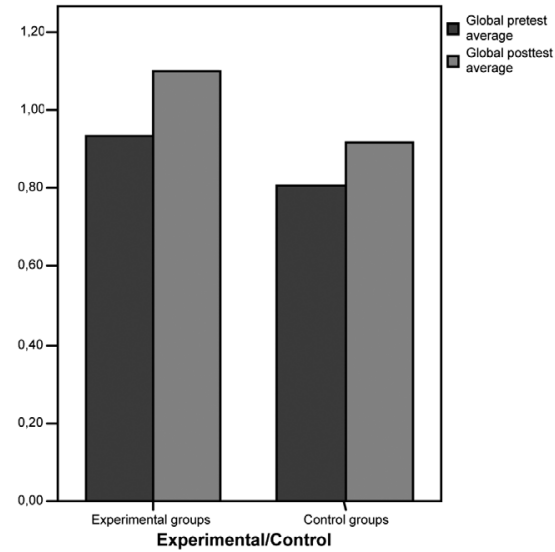


Differences in averages by group are clearer, as can be seen in Figure 3. If we order the groups by their differences between pretest and posttest results, we can see that there are greater differences between pretest and posttest results in experimental groups and fewer differences in control groups. The classification by groups can be seen in Figure 3. Interestingly, as we will see later in this paper, in the master's in Translation and New Technologies, which had the highest score, students and lecturers were more active in the improvement program (there were more activities with lecturers and more students completed more units of the OIL dossier).

TABLE 11

Results by group

\begin{tabular}{|c|c|c|}
\hline & Pretest & Posttest \\
\hline Master's in Translation and New Technologies (exp. group) & 1.03 & 1.20 \\
\hline Master's in Audiovisual translation (exp. group) & 0.87 & 1.05 \\
\hline Postgraduate course in Legal Translation (exp. group) & 0.81 & 0.96 \\
\hline Postgraduate course in Editing (control group) & 0.76 & 0.87 \\
\hline Postgraduate course in Literary Translation (control group) & 0.86 & 0.97 \\
\hline
\end{tabular}

FIGURE 4

Comparison between global pretest and posttest averages by group

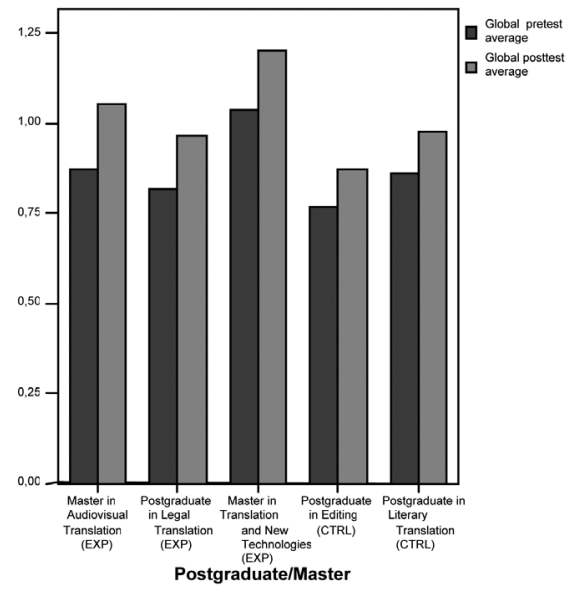

\subsection{Results on knowledge of occupational integration}

Items belonging to the area of knowledge on occupational integration have the highest results in the questionnaires. The results reveal that after studying a master's or postgraduate course, participants increase their knowledge of occupational integration, i. e., they have more information ("knowledge" understood as a synonym of "information"). The students' main concern during the master's course as for occupational integration is their lack of knowledge, and this is the first issue they want to address, and indeed they do address, during the master's course. In particular, they do not know about legal and fiscal issues, what clients want and what they offer, and so on. Students are very interested in discovering how the translation market works. Control groups show high results in this area. The highest score is for legal and fiscal 
issues presented in the master's and postgraduate courses. The lowest score is related to knowledge of free job centres outside university. This means that students pay attention to what the course offers them but they do not seek employment orientation outside their university course. After the master's or postgraduate course the identified need is satisfied and the objective is achieved because students know the professional market better. Improvement in this area may not be specifically a result of the OIL program but rather a result of specific content in the master's and postgraduate courses. However, the research is useful for the master's and postgraduate coordinators, because they had no previous recorded information about this issue.

FIGURES 5A-5B

Comparison between global pretest and posttest average on knowledge, global results and results by groups
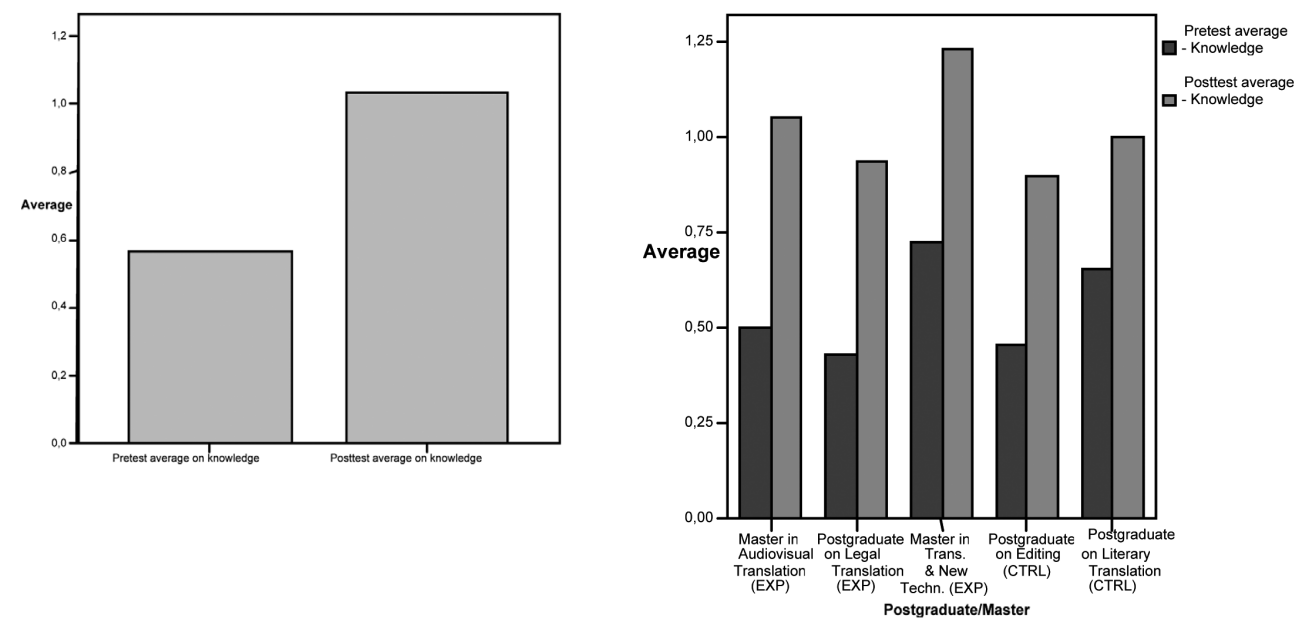

The global pretest average for knowledge was 0.56 , and the global posttest average was 1.03. The difference between pretest and posttest is much greater than in other areas, as it is the area that interests students the most. As seen in Figure 5B, the posttest average was significantly higher than the pretest average in all groups.

\subsection{Results on occupational integration skills}

In the skills areas there were greater differences in the results of control and experimental groups. This is precisely the area most influenced by the OIL improvement program. The lowest results are related to the active skills that require a proactive approach, such as creating a professional website or marketing oneself. In this area there were fewer differences in the averages between the control groups and the experimental groups. The clearest differences in skills development between groups are related to more passive skills or skills related to knowledge. New knowledge acquired during the master's course appears to have stimulated the development of related skills, such as drawing up a plan to look for work - if students have better knowledge of prospective clients and the translation market in general it is easier for them to produce a plan - and marketing one's skills to acquire new clients and make existing clients loyal. Interestingly, the more participative groups in the OIL program 
obtained higher results in the skills area because the OIL Program and activities with lecturers focused on improving skills. The results are as follows:

FIGURES 6A-6B

Comparison between pretest and posttest average on skills, global results and results by groups
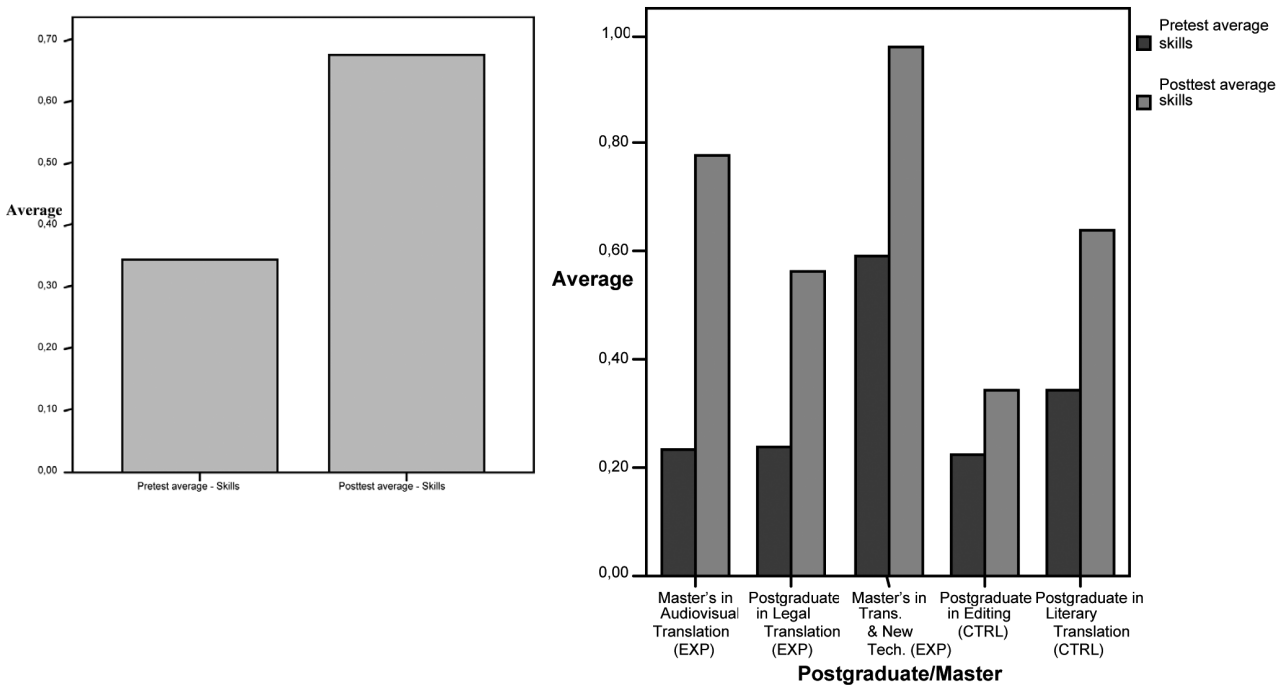

In the skills area, the global average increased from 0.34 (pretest) to 0.67 (posttest), as seen in Figure 6A. In this area there was a notable change in the Audiovisual Translation group, together with the other two experimental groups.

\subsection{Results for attitudes related to occupational integration}

In our initial evaluation, we identified the need to increase the time dedicated to finding work, and this was a specific aim of the improvement program. Specific activities strongly emphasised this aim as it was one with the lowest score in the pretest. In the posttest, very low results were observed (almost no difference between pretest and posttest), even though the more active group in the OIL improvement program scored higher than other groups that were not very involved in the improvement program. It might be that students were not interested in finding a job until they finish the master's course, or they had not time to devote to finding a job. Another reason may be that the program was not compulsory. Whatever the reason, we can say that increasing dedication to occupational integration was one of the aims of the program and it was not achieved the way we expected. Nevertheless, in later editions of the master's courses some contents on occupational integration were included and students would devote time to these contents as part of the master's course, which is more effective.

Another of the needs detected in the pretest was the improvement of professional maturity in the sense of professionals' will to improve their professional skills. In this area we observed an improvement in those areas already included in the master's course, such as reading about the profession. Between pretest and posttest there was an increase 
in the number of memberships of professional translators' associations, which is also a sign of professional maturity. For the attitude indicator "self-esteem," neither in the pretest nor in the preliminary context analysis did we observe the need for improvement, because the initial results were good. The final results show a small, but not significant improvement in self-esteem. Figures 7A and 7B show the global and group results.

FIGURES 7A-7B

Comparison between pretest and posttest average in attitudes, global results and results by groups
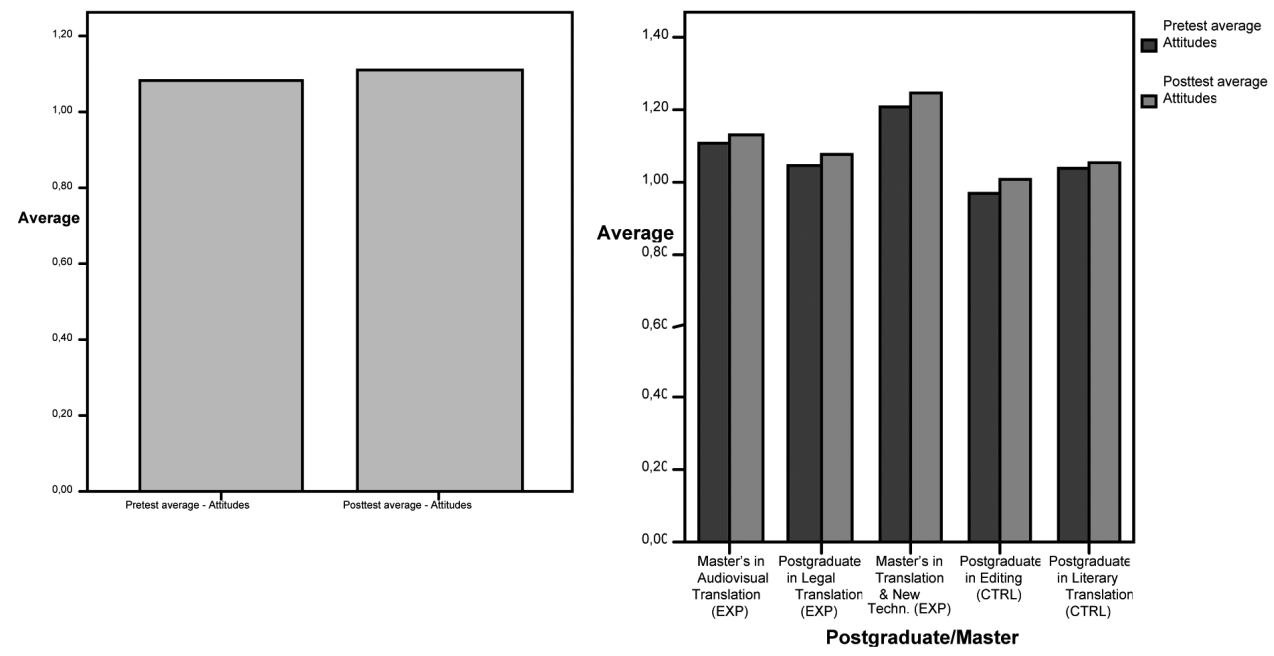

\section{Conclusion}

This research was useful in providing empirical data on the training for occupational integration that postgraduates receive during their postgraduate or master's courses. It also served to improve training already present in the courses. Moreover, the research introduced a working methodology for cross-sectional content into the master's and postgraduate courses, i.e., special programs, such as the occupational integration OIL Program. Regarding participation, while the lecturers' opinion of the experience was so positive that they were willing to include more activities related to occupational integration, students' participation in the research was voluntary, and we found that some of them did not take it too seriously.

The control groups showed very low results in the posttest in skills and attitudes. After the improvement program, the experimental groups' results showed an improvement in skills and attitudes, although their scores were not much higher. Improvement in knowledge is easier to achieve: before the master's course, a student "did not know," and after, the same student "does know." However, improvement in skills and attitudes is more difficult to achieve, even when a specific improvement program and activities are implemented, because they are related to "doing" and changing personal attitudes and beliefs.

In conclusion, knowledge on the market is not the only factor to take into account when looking for translation work. Unless postgraduates also develop the right skills and attitudes, which can be very difficult to develop, their chances of finding work will not improve. They need to combine knowledge, skills and attitudes, and find the 
right balance between the three. After the research our recommendation was to incorporate compulsory content to develop students' specific skills and attitudes into their master's and postgraduate courses, since these areas had the lowest results in the research. We made this recommendation to the master's and postgraduate course coordinators, and since 2006 specific content on occupational integration has been included in the syllabuses of four of the five courses (the postgraduate course in literary translation is no longer offered). Further research will be done on employment data after the inclusion of compulsory contents on occupational integration in the syllabus.

\section{ACKNOWLEDGEMENTS}

We would like to thank Dr. Montané and Dr. Rovira-Esteva for their supervision and advice throughout the research. We would also like to thank the Department of Translation and Interpreting of the Universitat Autònoma de Barcelona and the coordinators of the master's and postgraduate courses participating in the research for their support. Finally, we would like to thank lecturers and students for their participation in the research.

\section{NOTES}

1. Tradutech: Visited on 10 September 2012, <http://www.tradutech.net>.

2. Sources for Table 1, Table 2 and Table 3:

- ANECA Data: Graduates Questionnaire for the ANECA Project. Answers obtained in 2003 from 314 graduates from 12 universities: UA from Alicante, UPF, UVIC from Barcelona, UJI from Castelló, UGR from Granada, ULPGC from Las Palmas, UPCO from Madrid, UMA from Malaga, USA from Salamanca, Soria and Vigo.

- UAB/AQU Data and UAB/FTI Data: Data from Universitat Autònoma de Barcelona. There are two different studies: one coordinated by AQU (Agència de Qualitat del Sistema Universitari de Catalunya) from 2001 from 87 students who graduated in 1998 (UAB/AQU Data). The other one is from 2003 and carried out by the Faculty of Translation and Interpreting: 136 graduates between 1999 and 2002.

- UPCO Data: 121 students who graduated in 1997 y 1998 in Universidad Pontificia Comillas in Madrid. Questionnaire carried out in 1999.

- UJI Data: Report from the Observatori Ocupacional de l'Oficina de Cooperació Internacional i Educativa of Universitat Jaume I in 2003 «La inserció laboral dels titulats de la Universitat Jaume I. Promocions de 1998, 1999 i 2000. Informe per a la llicenciatura de Traducció i Interpretació», from 33 questionnaires.

3. It is worth mentioning that there were multiple answers. Graduates combine different jobs (fulltime, part-time and sporadic jobs). This is why percentages are over $100 \%$.

\section{REFERENCES}

Aguilar Río, José Miguel (2004): La enseñanza de la traducción y su relación con las exigencias del mercado laboral: estudio de caso. TRANS. 8:11-28.

Alcina-Caudet, Amparo (2003): Encouraging the Use of E-mail and Mailing Lists Among Translation Students. Meta. 48(4):634-641.

Aneca (2004): Libro blanco. Título de grado en Traducción e Interpretación. Madrid: Agencia Nacional de Evaluación de la Calidad y Acreditación.

Asadi, Paula and SÉguinot, Candace (2005): Shortcuts, Strategies and General Patterns in a Process Study of Nine Professionals. Meta. 50(2):522-547.

Aubert, Francis Henrik (1995): Translation Theory, Teaching and the Profession. Perspectives: Studies in Translatology. 3(1):121-131.

Borja, Anabel, Gamero Pérez, Silvia and Ruiz Antón, Juan Carlos (1998): El laboratorio de traducción como escenario didáctico. Quaderns. 2:143-154.

Bowker, Lynne (2004): What Does It Take to Work in the Translation Profession in Canada in the 21st Century? Exploring a Database of Job Advertisements. Meta. 49(4):960-972. 
Byrne, Jody (2003): Freelance Translation: Teaching Students to Create Their Own Jobs. In: Daniel Gouadec and Daniel Toudic, eds. Traduction, Terminologie, Rédaction. Paris: La Maison du Dictionnaire, 161-174.

CARsten, Svetlana (2002): What are the objectives in the curriculum design of an interpreting and translating programme? In: Belinda Maia, Johann Haller and Margherita UlyrCH, eds. Training the Language Service Provider for the New Millennium. Proceedings of the III Encontros de Traduçao de Astra-FLUP. Porto: Faculdade de Letras, 43-52.

Casas-Tost, Helena and Rovira-Esteva, Sara (2008): Chinese-Spanish translation studies in tertiary institutions in Spain: historical review and future perspectives. The Interpreter and Translator Trainer. 2(2):185-202.

Chaballe, Louis Yvon and Klein, Jean (1994): Formation et pratique de la traduction professionnelle en Belgique francophone. Meta. 39(1):69-77.

Chaume, Frederic (2003): Doblatge i subtitulació per a TV. Vic: Eumo.

Dam, Helle V. and Korning Zethsen, Karen (2009): Who said low status? A study on factors affecting the perception of translator status. Jostrans. 12:2-36.

Díaz Cintas, Jorge (2003): Teoría y práctica de la subtitulación inglés-español. Barcelona: Ariel.

Díaz Ferrero, Ana María and Sabio, José Antonio (2003): La traducción del portugués en España: enseñanza y perspectivas profesionales. In: Emilio Ortega Arjonilla, ed. Panorama actual de la investigación en traducción e interpretación. Granada: Atrio, 121-142.

Groethuysen, Cornelia (2002): Real-Life Training for Translators - Software Localisation and Technical Documentation. In: Belinda Maia, Johann Haller and Margherita UlyrCh, eds. Training the Language Service Provider for the New Millennium, Proceedings of the III Encontros de Traduçao de Astra-FLUP. Porto: Faculdade de Letras, 81-88.

Gromová, Edita and MüglovÁ, Daniela (2003): New Trends in Translation Training in Slovakia. In: Pilar Castaño, Tobias Tilman, Luis Pérez-González, et al., eds. La traducción y la interpretación en un entorno global. Villaviciosa de Odón (Madrid): Universidad Europea de Madrid.

JiméNez, Óscar (2002): La traducción técnica inglés-español. Didáctica y mundo professional. Granada: Comares.

Katan, David (2009): Occupation or profession. A survey of the translator's world. Translation and Interpreting Studies. 4(2):187-209.

KELLY, Dorothy (2004): La investigación sobre formación de traductores: algunas reflexiones y propuestas. In: Emilio Ortega Arjonilla, ed. Panorama actual de la investigación en traducción e interpretación. Granada: Atrio, 585-596.

Kiraly, Don (2000): A Social Constructivist Approach to Translator Education: Empowerment from Theory to Practice. Manchester: St. Jerome.

LAVAUlT-OlLÉON, Élisabeth (1998): Traduction en simulation ou en professionnel: le choix du formateur. Meta. 43(3):364-372.

Lung Jan Chan, Andy (2010): Perceived benefits of translator certification to stakeholders in the translation profession: A survey of vendor managers. Across. 11(1):93-113.

McDonough, Julie (2007): How do language professionals organize themselves? An Overview of Translation Networks. Meta. 52(4):793-815.

MontanÉ, Josep (1990): La orientación ocupacional: enfoques y técnicas. Actas VI Jornadas Nacionales de Orientación Educativa. (Puerto de la Cruz, 29 October-3 November) La Laguna: AEOEP.

MontanÉ, Josep (1993): La Orientación Ocupacional. Barcelona: CEAC.

Monzó, Ester (2002): La professió del traductor jurídic i jurat: descripció sociologica del professional i anàlisi discursiva del transgènere. Doctoral thesis, unpublished. Facultat de Ciències Humanes i Socials, Departament de Traducció i Comunicació. Castelló de la Plana: Universitat Jaume I.

ObSERVATORI OCUPACiONAL UJI (2003): La inserció laboral dels titulats de la Universitat Jaume I. Promocions de 1998, 1999 i 2000. Informe per a la llicenciatura de Traducció i d'Interpretació. Castelló de la Plana: Universitat Jaume. 
OPQ, Oficina de planificació i qualitat (2003): Informes d'inserció per titulacions - Traducció i interpretación. Bellaterra: Universitat Autònoma de Barcelona.

PaCte (2001): La competencia traductora y su adquisición. Quaderns. Revista de Traducció. 6:39-45.

PACTE (2002): Una investigación empírico-experimental sobre la adquisición de la competencia traductora. In: Amparo Alcina and Silvia Gamero-Pérez, eds. La traducción científicotécnica y la terminología en la sociedad de la información. Castelló: Universitat Jaume I, $125-138$.

PACTE (2005): Investigating Translation Competence: Conceptual and Methodological Issues. Meta. 50(2):609-619.

PARRA, Joan (2002): El mercado laboral en el sector de la localización. In: Amparo AlcinA and Silvia Gamero-PÉRez, eds. La traducción científico-técnica y la terminología en la sociedad de la información. Castelló: Universitat Jaume I, 207-214.

PÉrez Escoda, Núria (1996): Programa de formació per a la inserció laboral. Barcelona: Grupo Editorial CEAC.

Phillips, Montserrat (1996): La profesión del traductor e intérprete autónomo: aspectos técnicos. Aproximaciones a la traducción. Madrid: Centro Virtual Cervantes. Visited on 17 April 2013, <http://cvc.cervantes.es/lengua/aproximaciones/phillips.htm>.

Robinson, Douglas (1997): Becoming a Translator: An Accelerated Course. London: Routledge.

Roser, Nicolás (2004): Presente y futuro de la traducción del y al árabe en España. In: Emilio Ortega Arjonilla, ed. Panorama actual de la investigación en traducción e interpretación. Granada: Atrio.

SAmuelsson-Brown, Geoffrey (1998): A Practical Guide for Translators. Clevedon: Multilingual Matters LTD.

Sofer, Morry (2004): The Translator's Handbook. Washington: Schreiber Publishing, Inc.

Teichman, Diane E. (2003): Best Face Forward: In Person Marketing Skills for T\&I Professionals. Visited on 13 March 2009, <http://www.lexicool.com>.

Tirkkonen-Condit, Sonja (2005): The Monitor Model Revisited: Evidence from Process Research. Meta. 50(2):405-414.

TolnaI, Thomas (2008): Skills needed by freelance translators in order to enhance their reputation on the translation market. Studia Universitatis Babes-Bolyai - Philologia. 3:167-174.

Torres-Hostench, Olga (2010): An overview of the research on occupational integration in translation studies according to a map of occupational integration concepts. Perspectives. 18(1):23-38.

UlRYCH, Margherita (1996): Real-world criteria in translation pedagogy. In: Dollerup, Cay, ed. Teaching Translation and Interpreting 3. Amsterdam/Philadelphia: John Benjamins, 251-259.

VALERo, Carmen (2003): Traducción e interpretación en los servicios públicos: contextualización, actualidad y futuro. Granada: Comares.

Wagner, Emma, Bench, Sven and Martínez, Jesús M. (2002): Translating for the European Union Institution. Manchester: St. Jerome.

WaKabayashi, Judy (2002): Induction into the Translation Profession through Internet Mailing Lists for Translators. In: Eva Hung, ed. Teaching Translation and Interpreting 4. Building Bridges. Amsterdam/Philadelphia: John Benjamins, 47-58.

WaliczeK, Bartoz (2002): The Challenge of Market-Oriented Translation and Interpreting Curricula for Training Communication Specialists in Poland. In: Belinda MAIA, Johann Haller and Margherita Uly RCH, eds. Training the Language Service Provider for the New Millennium, Proceedings of the III Encontros de Traduçao de Astra-FLUP. Porto: Faculdade de Letras, 101-110.

WiLss, Wolfram (1996): Knowledge and Skills in Translator Behaviour. Amsterdam/Philadelphia: John Benjamins.

Wilss, Wolfram (1999): Translation \& Interpreting in the 20th Century: Focus on German. Amsterdam/Philadelphia: John Benjamins. 


\section{APPENDIX}

\section{Pretest-Posttest questionnaire}

Please answer these questions. Mark with an X the answer that is closest to your opinion.

[ ] 1 means "Not at all" - [ ] 2 means "A little" - [ ] 3 means "Quite a lot" -

[ ] 4 means "A lot"

Name Surname

Age.

Degree in. Year of finishing the degree

Postgraduate/Master's course. University

Current employment situation

[ ] I study

[ ] I study and work sometimes (less than part-time jobs)

[ ] I study and work part-time

[ ] I study and work full-time in a company

[ ] I study and work full-time as a freelancer

You would like to work as a

Do you have any experience in this job? [ ] 1 [ ] 2 [ ] 3 [ ] 4

How many months/years?

Do you have any experience in any other jobs? [ ] 1 [ ] 2 [ ] 3 [ ] 4

Mention other jobs you have had and the time you spent in those jobs.

1. Do you know what translation customers need from a translator (qualifications, types of translation services, ways of working, etc.)? [ ] 1 [ ] 2 [ ] 3 [ ] 4

2. Do you know what translation clients offer (rates, working conditions, etc.)?

[ ] 1 [ ]2[ ]3 [ ] 4

3. Do you know the legal and fiscal requirements to work as a freelance translator? [ ] 1 [ ]2[ ]3 [ ]4

4. Do you know how to use free employment orientation services provided by your local council? [ ] 1 [ ] 2 [ ] 3 [ ] 4

5. Is your professional website up to date? [ ] 1 [ ] 2 [ ] 3 [ ] 4

6. Have you distributed any marketing material, such as our website address or business cards, etc.? [ ]1 [ ]2[ ]3[ ] 4

7. Have you got any strategy or detailed plan to look for translation work?

[ ] 1 [ ]2[ ]3 [ ] 4

8. How do you look for translation work?

Family, friends and colleagues [ ] 1 [ ] 2 [ ] 3 [ ] 4

Press [ ] $1[$ ] 2 [ ] $3[$ ] 4

Translation job sites (proz.com, etc.) [ ] 1 [ ] 2 [ ] 3 [ ] 4

Internships at universities [ ] 1 [ ] 2 [ ] 3 [ ] 4

Temporary recruitment agencies [ ] 1 [ ] 2 [ ] 3 [ ] 4

Visits to companies [ ] 1 [ ]2 [ ] 3 [ ] 4

Self-promotion advertisements [ ] 1 [ ] 2 [ ] 3 [ ] 4

Others [ ] 1 [ ]2 [ ] 3 [ ] 4

9. Do you know how to sell translation services to a new client? [ ] 1 [ ] 2 [ ] 3 [ ] 4

10. Do you know how to keep clients satisfied? [ ] 1 [ ] 2 [ ] 3 [ ] 4

11. In the last 30 days, how many companies have you contacted by phone or visited personally? [ ] None or 1 - [ ] Between 2 and 5 - [ ] More than 5. 
12. In the last 30 days, how many CVs have you sent?

[ ] None or 1 - [ ] Between 2 and 5 - [ ] More than 5.

13. How many work interviews or translation tests have you arranged in the last 30 days?

[ ] None or 1.

[ ] 2 or 3.

[ ] More than 3.

14. How much time do you spend on marketing each week?

[ ] Less than 4 hours.

[ ] Between 4 and 8 hours.

[ ] More than 8 hours.

15. Would you be willing to do a training course on occupational integration if it would help you to find work? [ ] 1 [ ] 2 [ ] 3 [ ] 4

16. Your profession is ............................... and you would like to specialise but would you be willing to accept other, similar work? [ ] 1 [ ] 2 [ ] 3 [ ] 4

17. Would you accept a job for lower rates or with conditions that are not as good as you were expecting? [ ] 1 [ ]2 [ ] 3 [ ] 4

18. Would you accept a job requiring you to travel...

[ ] 30 minutes?

[ ] Between 30 and 60 minutes?

[ ] More than 60 minutes?

19. Would you accept a job with irregular working hours, such as working at weekends or at night? [ ]1 [ ]2[ ]3[ ]4

20. Are the things you read normally related to your profession? [ ] 1 [ ] 2 [ ] 3 [ ] 4

21. Are you a member of any professional associations? [ ] 1 [ ] 2 [ ] 3 [ ] 4

22. Do you think you know enough about new technologies applied to your profession? [ ] 1 [ ] 2 [ ] 3 [ ] 4

23. You are taking this postgraduate/master's course.....

[ ] Because you want to learn about your profession.

[ ] To find translaton work easily.

[ ] Both.

24. Do you consider yourself to be a good professional? [ ] 1 [ ] 2 [ ] 3 [ ] 4

25. Do your friends or work colleagues consider you to be a good professional? [ ] 1 [ ] 2 [ ] 3 [ ] 4

26. Do you think that you could offer your clients added value? [ ] 1 [ ] 2 [ ] 3 [ ] 4

27. Finding work is basically....:

[ ] A matter of perseverance and dedication.

[ ] A matter of luck.

[ ] Both.

28. Do you think you have already spent enough time looking for work and would now prefer to wait for companies to contact you once you have finished your postgraduate/master's course? [ ]1 [ ]2[ ]3[ ]4

29. Are you discouraged because you think it will be difficult to find work?

[ ] 1 [ ] 2 [ ] 3 [ ] 4

30. Do you think you will find the job you want soon? [ ] 1 [ ] 2 [ ] 3 [ ] 4 